\title{
INFLUENCES OF LEADERSHIP STYLE, COMPETENCE, AND WORK DISCIPLINE ON THE PERFORMANCE OF STATE OFFICIALS IN THE AGENCY OF INVESTMENT AND ONE-STOP SERVICE IN EAST HALMAHERA REGENCY, INDONESIA
}

\author{
Indah A Pratiwi \\ Ph.D. candidate \\ Satyagama University, Jakarta-Indonesia \\ Tjahja Supriatna \\ Professor of Public Policy Field of Government Institute Jatinangor-Indonesia
}

Josy Adiwisastra

Professor of Public Policy Field of Government Science Pajajaran University, Bandung -Indonesia

Dewi Sulistyani

Senior Lecturer, Satyagama University, Jakarta-Indonesia

DOI: $10.31364 / \mathrm{SCIRJ} / \mathrm{v} 8.112 .2020 . P 1220822$

http://dx.doi.org/10.31364/SCIRJ/v8.i12.2020.P1220822

\begin{abstract}
This study aims at examining the influences of leadership style, competence, and work discipline on the performance of State officials or briefly called ASN in the Agency of Investment and One-stop Service in East Halmahera Regency, Indonesia. The method to collect the data is by distributing the questionnaire to 100 samples of respondents. This data was analyzed by employing the multiple regression method. The results showed that there are positive and significant influences of leadership style, competence, and work discipline partially and jointly on the performance of ASN in the Agency of Investment and Onestop Service in East Halmahera Regency, Indonesia. Therefore, it is suggested that the local government of East Halmahera needs to give serious attention to these three variables to improve the performance of ASN who work in the Agency of Investment and One-stop Service. However, the caveat applies.
\end{abstract}

Keywords: Leadership Style, Competence, Work Discipline, ASN Performance

\section{INTRODUCTION}

The Agency of Investment and One-Stop Service is the agency that is introduced by the government of Indonesia to provide greater access for society to get qualified service in activities of licensing, non-licensing, and investment. It is also expected to be able to improve the investment climate in encouraging economic growth and providing attention to the role of micro, small, and mid-level businesses. This agency was established in the presidential period of Susilo Bambang Yudhoyono in 2005, and it has been developed after the issuance of Law number 25/2009 about public service. The establishment of this agency was based on the Regulation of East Halmahera Regent Number 4/2017 about the delegation of administrative authority inlicensing and non-licensing activities to the Investment and One-stop Service Agency (DPMPTSP).

The process to get the license issued by DPMPTSP is relatively simple. The applicant does not need to process several letters and documents to different agencies located in different places. By this method, it is expected the licensing process will be faster, easier, cheaper, more transparent, clearer, and more reachable. Also, it is expected that investors will be easier to come to the East Halmahera region and will add and develop other business and working opportunities especially for people in East Halmahera. By doing this, people especially young job seekers who are fresh graduates do not focus and compete only on becoming government officers (ASN). Recent condition in North Maluku, for example, has shown that young people prefer to work as government officers rather than start their own business which is more profitable if it is optimally carried out. Besides, there are various potentials in the sectors of mining, fishery, and agriculture of East Halmahera Regency.

However, the tasks and functions of the Investment and One-stop Service Agency have got direct complaints from the society as it does not work according to the standards and procedures of licensing service which is fast, easy, cheap, transparent, clear, and reachable. The complaints consist of: (1) the availability of officers dealing with the actual officers appointed to 
provide services; (2) indiscipline officers such as in willingness to provide service, especially in terms of their consistency of working hours based on the opening and closing time of the service; (3) Dissatisfaction with the attitude of officers in providing their services, especially when there are questions about completion and requirement processes which are not answered well, and it makes the process difficult; (4) Less communicative officers and no officers who are active in speaking a foreign language so that it makes the licensing process and the foreign investment realization difficult; (5) Long period of reviewing a licensing application by DPMPTSP; and (6) Quite longer period of the administrative process than what has been set in the service SOP of DPMPTSP.

Due to the above background, this study aims at examining the influences of leadership style, competence, and work discipline on the performance of ASN (State Civil Apparatus) in the Agency of Investment and One-stop Service in East Halmahera Regency, Indonesia. However, to systematize the discussion of this paper, the next section 2 deals with the literature reviews and hypotheses. Section 3 presents the detail of the research method. Section 4 deals with the results and discussion of the findings. Finally, the last section concludes the paper.

\section{LITERATURE REVIEW AND HYPOTHESES}

It was argued in the literature that the key factors influencing ASN performance are leadership style, competence, and work discipline. The role of a leader in influencing his subordinates is very important in the development of an institution or organization. Koesmono (2007:30) stated that a leader in an organization is necessary to take the organization to reach the goals that have been set. A leader usually employs a certain leadership style to influence his subordinates. According to Mas'ud (2001:123), leadership style is an action norm or style employed by a person when trying to influence the actions of other people or his subordinates.

The functions of a leader are, therefore, to direct, guide, order, and show his subordinates to make them happy, agree, guided, and obey what he wants and establishes. Also, a leader has a responsibility both physically and spiritually to the success of his subordinates working activities. The failure of a subordinate in carrying out his jobs shows the failure of a leader himself because the effectiveness and goal-directed works of the subordinate depends on the leader. A discussion on leader and leadership generally describes how to be a good leader, styles, appropriate characters, and requirements needed by a good leader. However, it is still difficult to implement all of those criteria, so that there are only a few leaders who can perform good leadership and to direct his subordinates to the expected condition.

The most required and the most important resource in an organization is human resources because it plays important role in the success of an organization. Either government or private institutions need human resources who have competencies, skills, and knowledge to carry out given jobs. ASN is a human resource or the most important organization asset to reach visions, missions, and goals of the organization. Moreover, employees are the most important means to organize human resources and organization needs either government or private. According to Hasibuan (2014:13), an employee is a person who sells his/her service or idea and deserves compensation to where he/she is attached and responsible for the jobs assigned to him/her. The role of ASN in a government institution is very important to help the organization in reaching visions and missions. The role of ASN in DPMPTSP is very important for East Halmahera regency as ASN is directly related to public service in the activities of licensing, non-licensing, and investment that can increase regional income and foreign exchange. Therefore, several components such as intellectual competence, emotional competence, and social competence are required to improve ASN performance in the organization.

The other factor influencing ASN performance is work discipline. Work discipline is a management action to encourage members of an organization or institution to meet several conditions. In other words, ASN discipline is a form of training to improve and shape the knowledge and attitude of ASNs so that they can be willingly cooperative with other ASNs and also improve their work achievements. Discipline is described as a system consisting of policies, regulations, and procedures organizing attitudes in an organization either individually or as a group. In the implementation, discipline is focused on individual ASN awareness to follow organization regulations (Susilaningsih, 2008:3). The implementation of discipline to ASN is expected to be able to improve ASN performance.

Kinerja is short for "Kinetika Energi Kerja" which is derived from the English word "Performance". It means the completion of a job using knowledge, skills, and competence. According to Rivai (2004:15), performance is a result of a person's level of success as a whole in a certain period to carry out a job compared to several possibilities such as work output standard, targets, goals, or criteria. The definition of performance is, therefore, outputs or work results that are produced well both qualitatively and quantitatively and can be accounted for their roles in an organization or institution along with competence, skills, and capability in finishing the job. Output or result is described as work effectiveness, quality, and efficiency at the task level. Setting up a target or performance standard is very important to do because individual performance can highly influence team performance in an organization.

\section{Hypothesis}


Four alternative hypotheses were tested in the study as follows.

1. There is a significant influence of leadership style on ASN performance in DPMPTSP of East Halmahera Regency.

2. There is a significant influence of competence on ASN performance in DPMPTSP of East Halmahera Regency.

3. There is a significant influence of work discipline on ASN performance in DPMPTSP of East Halmahera Regency.

4. There is a significant influence of leadership style, performance, and work discipline altogether on ASN performance in DPMPTSP of East Halmahera Regency.

\section{RESEARCH METHOD}

The method used to collect the data was mainly by using a quantitative survey The quantitative survey was conducted by distributing questionnaires to sample respondents. The sample size of this study was determined by using Slovin's formula ( see, Prasetyo and Jannah, 2007). The number of the sample size was 100 respondents. Note that, since the units of indicators of both dependent and independent variables estimated were not in numbers, we quantified these subjective preferential thinking feelings and action in a validated and reliable manner by Likert scale from 1 to 5 (from strongly disagree to strongly agree). See, Joshi, et.al. (2015).

After the questionnaires have been completed, we then analyzed these data by using multiple linear regression analyses with the help of the SPSS software program version 25. The model of multiple linear regression analysis can be written mathematically as follows.

$$
\hat{\mathrm{Y}}=\mathrm{a}+\mathrm{b}_{1} \mathrm{X}_{1}+\mathrm{b}_{2} \mathrm{X}_{2}+\mathrm{b}_{3} \mathrm{X}_{3}+\varepsilon
$$

Where:

$\mathrm{X}_{1}$

$\mathrm{X} 2$

$\mathrm{X} 3$

$\mathrm{Y}$

$\varepsilon$

$$
\begin{aligned}
& =\text { Leadership Style } \\
& =\text { Competence } \\
& =\text { Work Discipline } \\
& =\text { State Offcials performance } \\
& =\text { error terms. }
\end{aligned}
$$

It is worth noting that before the estimated model above was regressed, both reliability and validity tests to know how well the method used and the accuracy of a measure were firstly undertaken. Also, four key assumptions associated with the multiple linear regression, namely, linearity, normality, multicollinearity, and heteroscedasticity were examined (see, Sekaran \& Bougie, 2010; Gujarati, 2009 for detail statistical tests for OLS assumptions).

\section{RESULTS AND DISCUSSION}

\section{Validity and Reliability Test}

A validity test is conducted to measure the reliability of the data. A research instrument is considered valid or true if it has high validity and reliability toward what has to be measured. According to statistic calculation for each variable of 15 instrument items (questionnaire) with 100 respondents $(n=100)$ and the significance level of 0.05 , it is obtained higher value of $r$ calculated than r-table, so it is stated that all question items in the questionnaire are valid or true.

A test can be considered reliable but not necessarily valid. However, a test cannot be considered valid if it is not reliable. Therefore, consistency is a requirement to meet to get the validity of an instrument. A reliability test is employed to find out that an instrument is valid and reliable, and it will be still consistent if two or more measurements are conducted on the same group using the same instrument. In this technique, measurement is conducted only on one occasion, and then a comparison is made using other questions or using correlation measurement between questions in the questionnaire. The result of the reliability test shows that each reliability value or Alpha Cronbach is higher than 0.60 or Alpha Cronbach > Standard Alpha, so it can be stated that all question items are reliable.

\section{OLS Assumption Tests}

Four key assumptions associated with the multiple linear regression, namely, linearity, normality, multicollinearity, and heteroscedasticity were also examined. A Normality test is conducted to find out if data have a normal distribution. Normal P-P Plot is employed in this normality test. In Normal P-P Plot, normality can be principally detected by looking at the data distribution (dots) on the graphic diagonal axis or the residual histogram. On the normal probability plot, it can be seen that data 
dots form a linear pattern, so they can be considered consistent with the normal distribution, or all variables values in this research are larger than $0.05(5 \%)$, so they meet the normality requirement.

A linearity test is conducted to find out if two or more variables have a significant linear relationship or not. Linearity test is employed as pre-requirement in linear regression analysis. By employing the $\mathrm{F}$ test, it was found that there is a linear relationship between the three independent variables and the dependent variable. The multicollinearity and heteroscedasticity tests also showed that the model estimated did not violate both reliability and validity tests as well as the Ordinary Least Square (OLS) assumptions. Hence, the model was justifiable for inference or prediction.

\section{The influences of Leadership style, Competence and Work discipline on the Performace of State Officials}

By using a statistical program (SPSS version 25), as shown in tables 1 and table 2, all three independent variables have positive and significant influences on the dependent variable, both partially and jointly. This suggests that leadership style (X1), competence (X2), and work discipline (X3) have partial and joint effects on the performance of State Officials (Y). The partial significant effect of each of the independent variable on the performance of State Officials was shown in Table 1. The significant influence of each independent variable on the performance of ASN can be seen from the t-value and the Sig. value. As exhibited in Table 1, all the t-calculated value of each independent variable is higher than t- table and the sig value was less than 5 percent. These indicate that leadership style, competence, and work discipline significantly influence partially the ASN performance. Thus, the null hypothesis is rejected.

Table 1

Simple Linear Regression Analysis

\begin{tabular}{|c|c|c|c|}
\hline \multirow{2}{*}{ Free Variables } & \multicolumn{2}{|c|}{ t-test } & \multirow{2}{*}{ Note } \\
\hline & t-calculated & t-table & \\
\hline Leadership Style (X1) & 11.704 & 1.661 & Significant \\
\hline Competence (X2) & 11.160 & 1.661 & Significant \\
\hline Work Discipline (X3) & 10.105 & 1.661 & Significant \\
\hline \multicolumn{4}{|l|}{ ASN Performance (Y) } \\
\hline
\end{tabular}

Source: Output SPSS 25

Similarly, the joint influence of the three independent variables was found to be significant. This was shown from the Fcalculated value which is greater than the F- table at 5 percent level (Table 2). Thus, the null hypothesis is rejected and Ha is accepted. In other words, leadership style, competence, and work discipline jointly influenced ASN performance.

Table 2

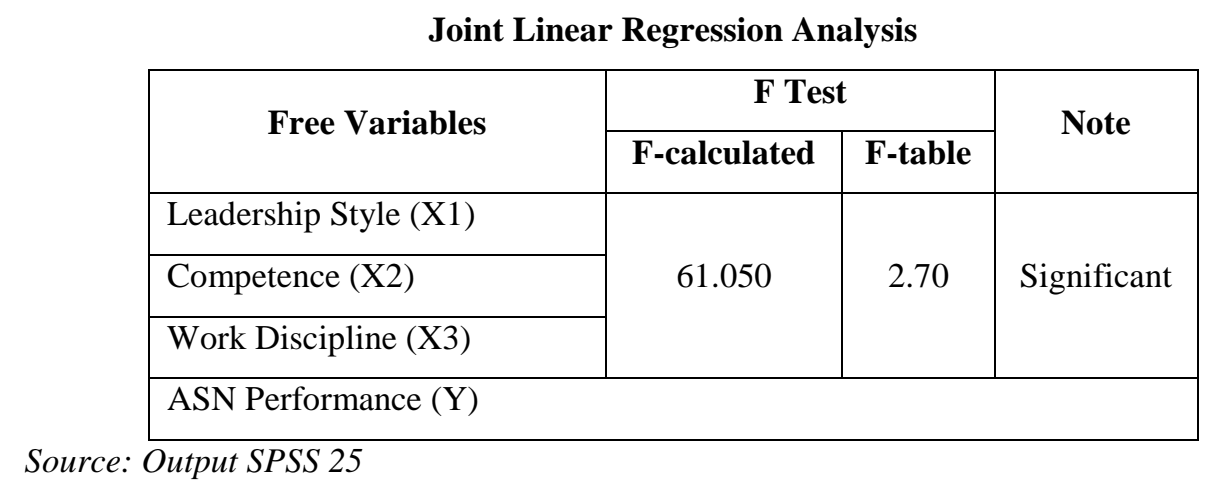

In terms of the coefficient determination $\left(\mathrm{R}^{2}\right)$, the estimated result showed that about 65.6 percent of the variance in the performance of ASN $(Y)$ is predicted or explained by linear regression and the predictor variables (leadership style, competence, and work Discipline), while the rest of $34,4 \%$ is explained by other variables (Table 3 ). 
Table 3

Determinant Coefficient

\begin{tabular}{|c|c|c|c|c|}
\hline \multicolumn{5}{|c|}{ Model Summary } \\
\hline Model & $\mathrm{R}$ & R Square & Adjusted R Square & $\begin{array}{c}\text { The standard error of the } \\
\text { Estimate }\end{array}$ \\
\hline 1 & $.810^{\mathrm{a}}$ & .656 & .645 & .33164 \\
\hline \multicolumn{3}{|c|}{ a. Predictors: (Constant) Leadership Style, Competence, and Work Discipline } \\
\hline
\end{tabular}

Source: Output SPSS 25

The result of the estimated multiple regression model was as follows.

$$
\hat{\mathrm{Y}}=0.702+0.358 \mathrm{X} 1+0.270 \mathrm{X} 2+0.216 \mathrm{X} 3
$$

The constant value of 0.702 means that the performance of ASN was 0.702 if there is no variable of Leadership Style (X1), Competence (X2), and Work Discipline (X3) or by the value of zero. Whilst the coefficient value of 0.358 unit means that if the variable of Leadership Style (X1) increases by 1 unit, and other variables of Competence (X2) and Work Discipline (X3) are constant, there will be an increase of ASN Performance (Y) by 0.358 unit, vice versa. Similarly, for the competence variable, if there is one unit increase, the ASN Performance $(\mathrm{Y})$ will increase by 0.270 , vice versa. Also, if the work discipline $\left(\mathrm{X}_{3}\right)$ increases by one unit, the ASN Performance (Y) will increase by 0.216 units, vice versa (Table 4$)$.

Table 4

Result of Multiple Linear Regression Model

\begin{tabular}{|c|c|c|c|c|c|}
\hline \multirow{2}{*}{ Model } & \multicolumn{3}{|c|}{\begin{tabular}{|l|l|} 
Unstandardized Coefficients & Standardized Coefficients
\end{tabular}} & \multirow{2}{*}{$\mathrm{t}$} & \multirow{2}{*}{ Sig. } \\
\hline & $\mathrm{B}$ & Std. Error & Beta & & \\
\hline 1 (Constant) & 0.702 & .239 & & 2.942 & .004 \\
\hline Leadership Style & 0.358 & .109 & .358 & 3.283 & .001 \\
\hline Competence & 0.270 & .106 & .278 & 2.549 & .012 \\
\hline Work Discipline & 0.216 & .084 & .245 & 2.585 & .011 \\
\hline
\end{tabular}

Source: Output SPSS 25

The findings above confirm that leadership Style, Competence, and Work Discipline have a significant influence on ASN Performance in the Investment and One-stop Service Agency of East Halmahera Regency both partially and jointly. However, the variable of Competence has the most significant influence on ASN Performance in the Investment and One-stop Service Agency of East Halmahera Regency, followed by the variable of Leadership Style and Work Discipline.

The ASN performance is related to public service that concerns with a greater aspect of life. The government has the function to provide several public services needed by society, from the service of setting up regulations to other services in health, education, licensing, and investment. One of the government's efforts to improve public service has been done for decades ago. One of which was through the Presidential Decree Number 5, 1984 about the Guidance of Simplification and Controlling Licenses in the business sector. The Presidential Decree was then continued by the Decree of the State Minister for the Empowerment of the State Apparatus Number 81/1993 about the Guidance of Public Service Administration. Presidential Decree in 1995 about Improvement and Development of Service Quality by the State Apparatus to the Society was then established to encourage the commitment of the State officials in improving their service quality. One recent improvement has been established by the Decree of Ministry of State Apparatur Number 63/KEP/M.PAN/7/2003 about the General Guidelines of Public Service Administration. Also, Act Number 25, 2009 about Public Service has also been established.

Society and foreign investors come from various backgrounds of education, profession, age, culture, ethnic group, nationality, and gender. There are various reasons for the licensing activity proposed by society and foreign investors. Service officers' knowledge and competence in the sectors of technology, information, attitude, and social and cultural systems will determine the quality of the One-stop service of the service officers. 
The efforts in improving ASN performance has been done not only by the establishment of government decrees but also by the improvement of ASN competence in providing public service. In the effort to improve the capacity of an organization in facing the more dynamic, turbulent, and inevitable environmental changes development, there are several strategies to take such as restructuring organization, changing market orientation, and developing building capacity.

There are several important factors in developing organization capability, but one of the most decisive factors in human resource. This is because the organization capability is developed by the competence of people inside the organization. In other words, machinery and several other facilities available in the organization are meaningless without the people who are competent and have the commitment to take action.

One of the strategies to improve the current public service is by improving ASN competence. This is simply because the more competent ASN, the more effective will be the employees' performance. This finding supports the previous study conducted by Peccei and Rosenthal (in Worsfold, 1999:278) which found that there is a strong causal relationship between employee commitment and customer service activities with the variable of capacity, knowledge, and competence. ASN who has competence can also provide qualified service. State officials (ASN) who commit to perform his job very well and according to the stand ard will be able to perform a better job and to provide a good service to the society and foreign investor so that they will invest their investment in especially East Halmahera Regency, and generally in Indonesia.

Of the competence indicators, the study found that social competence is the most important indicator. This is because this indicator can improve the ASN performance in the Investment and One-stop Service Agency of East Halmahera Regency. This finding was in line with the argument of Lako (1998:55) who states that the success of an organization in achieving its goal and in improving continuously is determined by the quality of its human resources. The finding also supports the argument of Spencer (1993:73) who states that the human resource factor is the most valuable asset. They particularly stated that social competence is comprehended as a combination of skill, personal attributes, and knowledge that is reflected in job behavior and can be observed, measured, and evaluated. With this competence, the performance of an employee can be predicted because competence is the main character in which a person shows good achievement in his job, role, and certain situation. Another study that supported this view was a study conducted by Boutler (1995:51). He argued that competence is the main modality in which a person can show a good achievement in his job, role, and certain situation. Thus, the significant influence of the competence variable verifies that the role of human resources is very strategic in improving ASN performance in the Investment and One-stop Service Agency of East Halmahera Regency.

In the variable of work discipline, the dimension that influences ASN performance the most is the compliance dimension of time regulation. It is based on the fact that most people's complaints on the ASN performance in the Investment and One-stop Service Agency of East Halmahera Regency are the availability of officers that deals with where and which are the officers who will provide the service. There is often no officer who is available during the operational working hours to provide the service. Indiscipline actions of a service officer are the less commitment of an officer in providing service especially in terms of the consistency of working hours in the operational hours. These indiscipline actions make the service becomes far from the standard of procedures of fast, easy, cheap, transparent, clear, and reachable.

The compliance dimension of time regulation in the Investment and One-stop Service Agency of East Halmahera Regency is important to implement the standardized and procedural public service. Moreover, no official websites in the Investment and One-stop Service Agency of East Halmahera Regency to make their service easier urges the officers to be active in providing the service to the society in person. Synchronization between information technology and ASN work discipline is expected to improve the public service process and ASN performance in the Investment and One-stop Service Agency of East Halmahera Regency. It is in line with what has been said by Robbins (2005:56) that one of the most important criteria is work discipline. Work discipline is defined as the attitude showing compliance on working time. The compliance consists of employee attendance and compliance with working hours and of employee performance to do well and in time.

In summing up: it can be confirmed that leadership style, competence, and work discipline play a significant influence on ASN performance in the Investment and One-stop Service Agency of East Halmahera Regency both partially and jointly. Therefore, to improve the ASN performance, these three variables should be given serious attention by the agency of the Investment and One-stop Service of East Halmahera Regency. If not, the establishment of the agency of the Investment and Onestop Service in East Halmahera Regency will be far from the expectation.

\section{CONCLUSION}

The study found that leadership style, competence, and work discipline have positive and significant influences on the performance of state officials or ASN performance in the Agency of the Investment and One-stop Service in East Halmahera Regency. This finding suggests the following. First, the leadership style of the chairman of the Investment and One-stop Service Agency of East Halmahera Regency need to understand the current situation and condition of his subordinates, as well as of the working environment. It should be highlighted that the situation and the condition should be in line with the corridors and the 
procedures and directed to the implementation of visions and mission of the Investment and One-stop Service Agency of East Halmahera Regency. In delegating the authority, the chairman of the agency needs to improve the licensing process to become easier and faster.

Second, any restructuring formation of ASN needs to be based on the regulated criteria including competence and performance. The ASN should be facilitated with education and training. They should also be motivated and facilitated with communication skills to make their service more efficient and friendly and to make them be able to answer questions about the process and mechanism of proposing an investment license and other relevant works. Third, there is a need to improve employees' discipline. This, for instance, can be done by tightening the attendance time of the employee regularly so that employees can be in the office during working hours. Finally, there is a need to improve the performance of ASN in the Agency of the Investment and One-stop Service of East Halmahera Regency by improving leadership style, competence, and work discipline in better shape. Thus much remain to be done.

\section{REFERENCES}

[1] Budiardjo, Miriam. (2007) Dasar Ilmu Politik. Jakarta: PT Gramedia Pustaka Utama.

[2] Dahl, Robert. (2001) Perihal Demokrasi. Jakarta: Yayasan Ekor Indonesia.

[3] Davis, W, and Newstroom D. (2004) Leadership Effectivity. Jakarta: PT Gramedia Pustaka Utama.

[4] Dharma, Winardi. (2001) Sistem Pengawasan Manajemen. Jakarta: Penerbit Quantum.

[5] Firstie, Helen dan Siti Medina. (2017) Pengaruh Gaya Kepemimpinan Kompetensi dan Motivasi terhadap Kinerja PNS Dinas Perhubungan Kabupaten Kapuas. STIE Pancasetia. Tersedia pada https://ejournal.stiepancasetia.ac.id/kindai/article/download/163/135/.

[6] Gibson, Paul. (1999) Performance Management. London: Paul Chapman Publishing.

[7] Handoko, Hani. (2005) Manajemen Personalia dan Sumberdaya Manusia. Edisi II, Cetakan Keempat Belas, Yogyakarta: Penerbit BPFE.

[8] Hasibuan, Malayu S.P. (2002) Manajemen Sumber Daya Manusia. Jakarta: Bumi Aksara.

[9] Hersey and Blanchard. (2005) Management Edisi ke-13. New Jersey: Prentice-Hall.

[10] Imam, Saydam. (2003) Disiplin kerja dalam organisasi. Jakarta: Gramedia.

[11] Irawan (2001) Manajemen Sumber Daya Manusia (Manajemen Kinerja kepegawaian). Bandung: CV. Mandar Maju.

[12] J, Wajong (1975) Asas dan Tujuan Pemerintahan Daerah. Jakarta: Jambatan.

[13] Jackson and Mathis. (2010) Management Human Resources. London: Prentice Hall Inc.

[14] Kreitner, Robert, and Kinicki Angelo. (2005) Perilaku organisasi buku edisi ke 5. Jakarta : Salemba empat.

[15] Linkage. (2009) Management, 5th edition. New Jersey-:Prentice Hall Inc.

[16] Locke. (2001) Influence leadership behaviors, job satisfaction, performance the effect of organizational commitment. (unpublished).

[17] Mangkunegara, Anwar Prabu. (2001) Manajemen sumber daya manusia perusahaan. Bandung :Remaja Rosdakarya.

[18] Marudut, Sitanggang. (2011) Pengaruh Kompetensi disiplin kerja, dan motivasi terhadap Produktivitas PNS biro Perencanaan Sekretariat jendral Departemen Pertahanan. (Tidak diterbitkan).

[19] Mas’ud, Fuad.(2001) Gaya kepemimpinan dalam kinerja Yogyakarta: Universitas Gajah Mada .

[20] Muhadam, Labolo.(2006) Memahami ilmu Pemerintahan. Jakarta: PT Grafindo Perkasa.

[21] Palan . (2007) Competency Management. Cetakan kedua. Jakarta Pusat : PPM.

[22] Poelje, D.G.A.(1953) Algemene inleiding tot de bestuurskunde Samson N. V. : Alphen aan den Reinjn inleinding tot bestuurswetenschap vuga Boekerij.

[23] Prihadi. (2004) Kinerja Aspek pengukuran. Jakarta :PT Gramedia Pustaka.

[24] Priyanto dan Suprapto. (2001) Management SDM Jakarta: PT Gramedia Pustaka Utama

[25] Rivai, Veithzal. (2009) Manajemen Sumber Daya Manusia Untuk Perusahaan. Jakarta: PT. Raja Grafindo Persada.

[26] Robbin. (2004) Management, 7th edition. New Jersey: Prentice Hall, Inc.

[27] Roe, Robert A. (2001) Trust Implementation for Performance \& Efectivines Europan Journal Vol 12 no 5.

[28] Salim, Sudarman. (2002) Metode Sistem Kinerja. Bandung: Alfa beta.

[29] Sanjaya, Budiyanto. (2010) Kompetensi dalam Kinerja. Jakarta :PT Gramedia Pustaka Utama

[30] Saragih, Juli, Panglima. (2003) Desentralisasi Fiskal dan Keuangan Daerah dalam otonomi. Jakarta : PT Ghalia Indonesia.

[31] Shafritz, Jay M \& E,W, Russell. (1997) Introducing Public Administration. USA: Longman.

[32] Simamora, Henry. (2004) Manajemen Sumber Daya Manusia Edisi Ke-3. Jakarta: PT Gramedia.

[33] Sirait, William. (2005) Management Kompetensi. Yogyakarta: Andi Offset.

[34] Smith and Millership. (2007) Performance Management organization. Edisi ke-17. London: Prentice-Hall.

[35] Spencer, M., Lyle, Jr, \& Signe M. Spencer. (1993) Competence at Work “Models for Superior Performance”. New York: John Wiley \& Sons Inc.

[36] Sunda, Cliff, Johny Lumolos, dan Sarah Sambiran. (2017) Kinerja Aparatur Sipil Negara dalam Pelayanan Publik pada Kecamatan Kawangkoan Utara. Universitas Samratulangi. Tersedia pada https://ejournalunstrat.ac.id/index.php/jurnaleksekutif/article/view/1543/. 
[37] Suparno. (1999) Mangelola Kompetensi dalam MSDM. Jakarta: Bumi Aksara.

[38] Stoner, J.A.F., Freeman, R.E., dan Gilbert. (2005) Management Edisi ke-13. New Jersey : Prentice Hall [39] S, Wibawa. (2009) Politik Perumusan Kebijakan Publik. Yogyakarta :PT Graha Ilmu [40] Wibowo. (2007) Manajemen Kinerja. Edisi Ketiga. Jakarta: Rajawali Press

[41] Wibowo. (2009) Managemen Sumber daya manusia. Yogyakarta:Universitas Atma Jaya. 